\title{
Emergency contraception - a neglected option for birth control
}

\author{
Eka R. Gunardi, Darrell Fernando
}

Department of Obstetrics and Gynecology, Faculty of Medicine, Universitas Indonesia, Cipto Mangunkusumo Hospital, Jakarta, Indonesia

\begin{abstract}
Abstrak
Kontrasepsi darurat adalah metode kontrasepsi yang digunakan pasca-sanggama dan sebelum perkiraan waktu implantasi, yang bertujuan mencegah kehamilan pasca-hubungan seks yang tidak terlindung atau kasus perkosaan. Penggunaan kontrasepsi darurat dapat menurunkan angka kehamilan yang tidak diinginkan hingga 50\%, tetapi sayangnya banyak tenaga medis dan masyarakat yang belum mengenal metode ini. Terdapat dua metode kontrasepsi darurat, yaitu pil kontrasepsi darurat dan alat kontrasepsi dalam rahim (AKDR) yang menggunakan tembaga. Terdapat dua regimen pil kontrasepsi darurat, yaitu regimen levonorgestrel dan regimen kombinasi. Regimen levonorgestrel memiliki efektivitas yang lebih baik dan menghasilkan lebih sedikit efek samping bila dibandingkan dengan regimen kombinasi. Pil kontrasepsi darurat harus diberikan sesegera mungkin setelah hubungan seks tidak terlindungi, dan paling efektif bila diberikan dalam waktu 24 jam. AKDR sebagai kontrasepsi darurat dapat dipasang hingga 5 hari pasca-hubungan seks tidak terlindungi. Kontrasepsi darurat terutama bekerja dengan mencegah fertilisasi, dan tidak menggugurkan kehamilan. Kontrasepsi darurat sangat aman, sehingga dapat ditawarkan kepada wanita yang telah melakukan hubungan seks tidak terlindungi dan ingin mencegah kehamilan. Meskipun demikian, kontrasepsi darurat hanya bersifat sebagai metode cadangan, tidak digunakan sebagai metode kontrasepsi reguler. (Med J Indones. 2013;22:248-52. doi: 10.13181/mji.v22i4.609)
\end{abstract}

\begin{abstract}
Emergency contraception (EC) is any method of contraception which is used after intercourse and before the potential time of implantation, in order to prevent pregnancy after an unprotected or inadequately protected sexual intercourse, or cases of rape. Use of emergency contraception could halve the number of unintended pregnancies and the consequent need for abortion, but unfortunately many medical professionals and the public are not aware of it. Two methods are available for emergency contraception, namely emergency contraception pills (ECPs) and copper-bearing intrauterine devices (Cu-IUDs). There are two regimens of ECP, the levonorgestrel regimen and combined regimen. The levonorgestrel regimen is preferred as it is more effective and causes less side effects. ECPs should be administered as soon as possible after unprotected or inadequately protected sex, being most effective if initiated within 24 hours. $\mathrm{Cu}$-IUDs can be inserted up to 5 days after unprotected sexual intercourse. Emergency contraception mainly works by preventing fertilization, and does not interrupt and established pregnancy. Emergency contraception is very safe, therefore can be offered to women who have had unprotected intercourse and wish to prevent pregnancy. It must only be used as a backup method of birth control. (Med J Indones. 2013;22:248-52. doi: 10.13181/mji.v22i4.609)
\end{abstract}

Keywords: Birth control, copper-IUD, emergency contraception, emergency contraceptive pills, levonorgestrel

Emergency contraception (EC) refers to any method of contraception which is used after intercourse and before the time of implantation. ${ }^{1}$ After fertilization, the zygote passes through the fallopian tube and reaches the uterine lumen after 4 days and finally undergoes implantation after 51/2-6 days. ${ }^{2}$ Therefore, use of emergency contraception aims to prevent pregnancy after an unprotected or inadequately protected sexual intercourse, or cases of rape. ${ }^{3,4}$

Alternative terms such as "morning-after pills" or "postcoital contraception" are often confusing and misleading, thus "emergency contraception" is the preferred term. ${ }^{5}$ The term "emergency" also stresses that it should only be used occasionally, as a backup to other methods of contraception. ${ }^{1}$

The Indonesian Ministry of Health has emphasized the importance of emergency contraception for the prevention of unwanted pregnancies. The majority of unwanted pregnancies end with abortion, many of which are unsafe thus leading to increased maternal mortalities. ${ }^{6}$ Use of emergency contraception could halve the number of unintended pregnancies and the consequent need for abortion. ${ }^{7}$ Unfortunately, in Indonesia many women are unaware of its existence or do not use it when needed. Moreover, there has been no established data regarding the use of emergency contraception in Indonesia.

\section{HISTORY}

Traditional forms of emergency contraception have been used for decades. These methods include douching with carbonated drinks, baking soda, or urin, or consuming high doses of vitamin $\mathrm{C}$, aspirin, or chloroquine. Effectiveness of these methods are doubted and may be unsafe to the woman.

The first form of modern emergency contraception roots back to the 1920 s, when veterinarians administered estrogens to dogs and horses that had mated. The first 
documented case was published in the mid-1960s, when physicians in the Netherlands administered postcoital estrogen to a rape victim. Around the same time in the United States, high-dose estrogen preparations such as ethinyl estradiol and diethylstilbestrol (DES) were also thoroughly researched and became the standar regiments. The regimen was called the " $5 \times 5$ " regimen, in which $5 \mathrm{mg}$ of estrogen was given each day for 5 days. In the early 1970s, Albert Yuzpe developed combined estrogen-progestin preparations, later known as the "Yuzpe method". Progestin-only postcoital contraception was also developed around the same time..$^{5}$ In 1998, World Health Organization (WHO) conducted a large trial at 21 centers worldwide comparing the Yuzpe regimen with levonorgestrel, and the results revealed better effectiveness and less side effects with levonorgestrel. Since then combined estrogen-progestin products were gradually withdrawn from some markets. ${ }^{8}$

Copper-bearing intrauterine devices was first studied for use as emergency contraception in the late 1970s. New methods such as danazol and mifepristone have not yet been extensively researched, although they may seem promosing as emergency contraceptives. ${ }^{5}$

\section{Methods of emergency contraception}

Various methods are available for emergency contraception, but until recently only two have been recommended by WHO: emergency contraception pills (ECPs) and copper-bearing intrauterine devices (Cu-IUDs). ${ }^{4}$ The levonorgestrel intrauterine system is not currently recommended for use as an emergency contraception. ${ }^{1,3}$

There are two types of ECPs preparations: levonorgestrel pills and combined ethinyl estradiol- levonorgestrel pills. ${ }^{3}$ All ECPs are administered orally. Because levonorgestrel has been proved to be more effective and produce less side effects than combined regimens, WHO only recommends levonorgestrel for emergency contraceptive use. ${ }^{4}$ Dosage of ECPs are shown in table 1 .

ECPs should be administered as soon as possible after unprotected or inadequately protected sex. The timing or initiation of emergency contraception is independent of the menstrual cycle day. ${ }^{9}$ Although the time limit for the first dose of emergency contraception is 120 hours (5 days) after unprotected intercourse, it has to be noted that the effectiveness of this method decreases over time. ${ }^{3,4}$ Treatment initiated within 72 hours (3 days) after unprotected intercourse reduces the risk for pregnancy by at least $75 \%$, and it is most effective if used within 24 hours. $^{7}$ WHO reported the pregnancy rate of levonorgestrel is $1.1 \%$, compared with $3.2 \%$ for the combined regimen. ${ }^{8}$ ECPs may be used more than once, even within the same menstrual cycle. ${ }^{3}$

$\mathrm{Cu}-\mathrm{IUD}$ is the most effective form of emergency contraception, reaching 99\% effectiveness if inserted up to 5 days after unprotected intercourse. ${ }^{4,10}$ Once inserted, this method may also serve as an ongoing long-term contraceptive. ${ }^{4} \mathrm{Cu}-\mathrm{IUD}$ is also preferred if the woman is taking liver enzyme-inducing drugs or within 28 days of stopping liver enzyme-inducing drugs, or if she is experiencing persistent nausea or vomiting with ECPs. ${ }^{11}$ The most effective $\mathrm{Cu}-\mathrm{IUD}$ s are those who have at least $380 \mathrm{~mm}^{2}$ of copper and have banded copper on the arms. ${ }^{12}$

Other regimens that can be used as emergency contraception include mifepristone, a progesterone receptor antagonist, and ulipristal acetate (UPA), a progesterone receptor modulator. A recent meta-

Table 1. Dosage of ECPs ${ }^{1,3,4}$

\begin{tabular}{|c|c|c|c|}
\hline ECP regimen & Dose & Efficacy $^{8 *}$ & Remarks \\
\hline Levonorgestrel & $\begin{array}{l}1.5 \mathrm{mg} \text {, single dose } \\
\text { OR } \\
750 \mu \mathrm{g}, 2 \text { doses taken } 12 \\
\text { hours apart }\end{array}$ & $\begin{array}{l}\leq 24 \text { hours: } 95 \% \\
25-48 \text { hours: } 85 \% \\
49-72 \text { hours: } 58 \%\end{array}$ & $\begin{array}{l}\text { - More effective and less nausea \& } \\
\text { vomiting than combined regimens. } \\
\text { - Single-dose regimen is equally } \\
\text { effective as the two-dose regimen. } \\
\text { - First dose is taken as soon as possible } \\
\text { after intercourse, and the second } \\
\text { dose is taken } 12 \text { hours later. }\end{array}$ \\
\hline Combined & $\begin{array}{l}100 \mu \mathrm{g} \text { ethinyl estradiol }+ \\
500 \mu \mathrm{g} \text { levonorgestrel, } 2 \\
\text { doses taken } 12 \text { hours apart }\end{array}$ & $\begin{array}{l}\leq 24 \text { hours: } 77 \% \\
25-48 \text { hours: } 36 \% \\
49-72 \text { hours: } 31 \%\end{array}$ & $\begin{array}{l}\text { - Antiemetics may be given } 1 \text { hour } \\
\text { before the first dose to reduce the } \\
\text { risk of nausea and vomiting. } \\
\text { - A two-dose regimen is recommended } \\
\text { as a single dose does not suppress } \\
\text { ovulation as efficiently as two-doses. }\end{array}$ \\
\hline
\end{tabular}

* when consumed within the listed hours following unprotected intercourse 
analysis of 100 trials revealed intermediate-dose mifepristone $(25-50 \mathrm{mg})$ and UPA were superior to levonorgestrel and combined regimens. ${ }^{13}$ A single dose of $30 \mathrm{mg}$ UPA has been approved in Europe and the United States for emergency contraception up to 120 hours after unprotected intercourse. Mifepristone for emergency contraception is mainly used in China. ${ }^{9}$

\section{Mechanism of action}

There are several mechanisms on how emergency contraception prevents pregnancy. These mechanisms include interference with sperm function, inhibition of ovulation, altered tubal function, and altered endometrial receptivity. ${ }^{9}$ Emergency contraception does not have any post-fertilization effect and does not act as an abortifacient. ${ }^{7}$

Levonorgestrel in EC doses has no direct effect on sperm function. It may trap the spermatozoa by thickening the cervical and intrauterine mucus, but it is not the main mechanism of action as an emergency contraception. ${ }^{9}$ On the other hand, $\mathrm{Cu}$ ions from $\mathrm{Cu}-$ IUD are toxic for spermatozoa and may enhance the inflammatory response, thus affecting their function and viability. ${ }^{4}$ Plastic IUDs without copper do not show these effects, thus are no longer used..$^{14}$

The main mechanism of levonorgestrel is by inhibiting follicular rupture and ovulation. ${ }^{9}$ This is achieved by inhibiting the rise in luteinizing hormone (LH). If administered 2 or 3 days before the LH peak, the LH peak was inhibited or delayed and blunted. Administration of levonorgestrel on the LH peak day or one day before failed to inhibit ovulation. ${ }^{9}$
Treatment with large doses of progesterone has shown to significantly reduce the beat of cilia in the fallopian tube. ${ }^{15}$ Progesterone also shows a dose-dependent effect on tubal muscular contractions. ${ }^{16}$ Nevertheless, use of levonorgestrel does not increase the risk of ectopic pregnancy, as they are also effective in reducing pregnancy itself. ${ }^{17} \mathrm{In}$ women using $\mathrm{Cu}$-IUDs, much less oocytes can be recovered from the fallopian tube and uterus..$^{18} \mathrm{As} \mathrm{Cu}$ ions from $\mathrm{Cu}$-IUDs are also found in tubal fluid and tubal epithelium, these findings suggest that $\mathrm{Cu}$ may have a role in oocyte or zygote destruction in the fallopian tube. ${ }^{14}$

Despite the early hypothesis that levonorgestrel can alter the endometrial receptivity, recent studies have shown that treatment with levonorgestrel did not affect endometrial receptivity nor gene expression profiling. ${ }^{9}$ In contrast, $\mathrm{Cu}$-IUD has been shown to stimulate myometrial contractility and induce a foreign body inflammatory reaction at the endometrium lining and at the uterine cavity, thus it works by mainly preventing implantation, rather than interrupting the process. ${ }^{18}$

\section{Indications and contraindications}

WHO has clearly defined when emergency contraception should be used. These indications are listed in Table 2.

Contraindications for ECP are pregnancy and known allergy to any of the consitituens. ${ }^{1}$ However if pregnancy occur after taking ECPs or the woman takes the pills after she becomes pregnant, the woman should be assured that the pills will not harm the mother or the fetus. ${ }^{4,9}$ Breastfeeding and past history of ectopic pregnancy are not contraindications for emergency contraceptive pills. ${ }^{19}$ Nevertheless, it is

Table 2. Indications for emergency contraception ${ }^{4}$

\begin{tabular}{ll}
\hline Indication & Remarks \\
\hline No contraceptive usage & \\
Contraceptive failure or & - Condom breakage, slippage, or incorrect use \\
incorrect use & - Three or more consecutively missed combined oral contraceptive pills \\
& - Progresterone-only pill (minipill) taken more than 3 hours late (or more than 12 hours late if taking a \\
& 0.75 mg desogestrel-containing pill) \\
- Norethisterone enanthate progestogen-only injection taken more than 2 weeks late & - Depot-medroxyprogesterone acetate (DMPA) progestogen-only injection taken more than 4 weeks late \\
- Combined estrogen-progestogen monthly injection taken more than 7 days late & - Dislodgment, delay in placing, or early removal of a contraceptive hormonal ring or skin patch \\
& - Dislodgment, breakage, tearing, or early removal of a diaphragm or cervical cap \\
& - Failed withdrawal (ejaculation in the vagina or on external genitalia) \\
& - Failure of a spermicide table of film to melt before intercourse \\
& - Miscalculation of the periodic abstinence method, or failure to abstain or use a barrier method on the \\
& fertile days of the cycle \\
- Expulsion of an IUD or hormonal contraceptive implant & In cases of sexual assault or rape when the woman was not protected by an effective contraceptive method \\
\hline Sexual assault or rape $\quad$
\end{tabular}


Table 3. Side effects of emergency contraception ${ }^{1}$

\begin{tabular}{lll}
\hline Method & Side effects or complications & Remarks \\
\hline ECP & Nausea, vomiting, dizziness, fatigue & $\begin{array}{l}\text { - If the woman vomits within the first 2 hours after } \\
\text { taking ECPs, the dose should be repeated. }\end{array}$ \\
& $\begin{array}{l}\text { - Frequency use of emergency contraception may cause } \\
\text { menstrual irregularities. }\end{array}$ \\
Pu-IUD & $\begin{array}{l}\text { Pelvic pain, abnormal bleeding, pelvic } \\
\text { infection, uterine perforation, expulsion }\end{array}$ & \\
\hline
\end{tabular}

recommended to postpone breastfeeding for at least 8 hours after consumption of levonorgestrel pills, but not exceeding 24 hours. ${ }^{9}$ In women with history of severe cardiovascular complications, angina pectoris, migraine, and severe liver disease, the advantages of emergency contraception outweigh the theoritical or potential risks. ${ }^{19}$ Smokers and advanced aged women may also use emergency contraception as the duration of hormonal use is very brief.

The only absolute contraindication of $\mathrm{Cu}$-IUD is pregnancy. ${ }^{4}$ History of recent pelvic inflammatory disease and current vaginal or cervical infection should also be ruled out before IUD insertion.

\section{Safety and side effects}

ECP and $\mathrm{Cu}$-IUD are very safe methods of emergency contraception. ${ }^{4}$ Nevertheless, some complications or side effects may occur, and these are listed in table 3 .

\section{Clinical setting}

For patients requesting emergency contraception, history taking is important to determine the time of unprotected intercourse and to rule out a possible preexisting pregnancy. Urine pregnancy tests are rarely required to rule out pregnancy. ${ }^{1}$ Clinical evaluation is indicated for women who have used emergency contraception if menses are delayed by a week or more, or if lower abdominal pain or persistent irregular bleeding develops. ${ }^{3}$

After prescribing ECPs or $\mathrm{Cu}-\mathrm{IUD}$, the patient has to be reminded that some irregular bleeding or spotting may occur in the following week or month, but may resolve without treatment. ${ }^{3}$ The next menses will usually occur within 3 weeks of taking ECPs. ${ }^{1}$ If the expected menstruation is more than 7 days late or lighter than usual, she should be advised to have a pregnancy test. The patient needs to be assured that use of emergency contraception will not effect future fertility, but also reminded that emergency contraception only serves as a back-up method and does not protect against sexually transmitted infections. ${ }^{4}$

\section{Recommendations}

Emergency contraception can be offered to women who have had unprotected intercourse and wish to prevent pregnancy. Emergency contraceptive pills can be used up to 72 hours after intercourse, while $\mathrm{Cu}$ IUD can be inserted up to 120 hours after intercourse. To achieve maximum efficacy, ECPs should be given as soon as possible after unprotected intercourse. The levonorgestrel regimen is more effective and passes lesser side effects than the combined regimen. A single dose of $1.5 \mathrm{mg}$ of levonorgestrel or two doses of $750 \mu \mathrm{g}$ taken 12 hours apart are equally as effective. Emergency contraception should only be used as a backup method, not as a regular method of birth control.

\section{REFERENCES}

1. Dunn S, Guilbert E. Emergency contraception. J Obstet Gynaecol Can. 2012;34(9):870-8.

2. Sadler TW. Langman's medical embryology. 11th ed. Philadelphia: Wouters Kluwer/Lippincott Williams \& Wilkins; 2010.

3. Armstrong C. ACOG Recommendations on Emergency Contraception. Am Fam Physician. 2010;82(10):1278.

4. World Health Organization [Internet]. Emergency contraception [updated 2012 July; cited 2013 October 10]. Available from: http://www.who.int/mediacentre/ factsheets/fs244/en/

5. Ellertson C. History and efficacy of emergency contraception: beyond Coca-Cola. Fam Plann Perspect. 1996;28(2):44-8.

6. Dirjen Bina Kesehatan Ibu Kementerian Kesehatan RI [Internet]. Factsheet: kontrasepsi darurat [updated 2013]. Available from: http://www.kesehatanibu.depkes.go.id/wpcontent/uploads/downloads/2013/01/Factsheet_Kondar. pdf. Indonesian.

7. Trussell J, Jordan B. Mechanism of action of emergency contraceptive pills. Contraception. 2006;74(2):87-9.

8. Task Force of Postovulatory Methods of Fertility Regulation. Randomised controlled trial of levonorgestrel versus the Yuzpe regimen of combined oral contraceptives for emergency contraception. Lancet. 1998;352(9126):428-33.

9. Gemzell-Danielsson K, Berger C, P GLL. Emergency contraception-mechanisms of action. Contraception. 2013;87(3):300-8. 
10. Committee on Health Care for Underserved W. ACOG Committee Opinion Number 542: Access to emergency contraception. Obstet Gynecol. 2012;120(5):1250-3.

11. National Intitute for Health and Clinical Excellence [Internet]. Contraception - emergency [cited 2011]. Available from: http://cks.nice.org.uk/contraceptionemergency - !topicsummary.

12. Kulier R, O'Brien PA, Helmerhorst FM, Usher-Patel M, D'Arcangues C. Copper containing, framed intra-uterine devices for contraception. Cochrane Database Syst Rev. 2007;4:CD005347.

13. Cheng L, Che Y, Gulmezoglu AM. Interventions for emergency contraception. Cochrane Database Syst Rev. 2012;8:CD001324.

14. Ortiz ME, Croxatto HB, Bardin CW. Mechanisms of action of intrauterine devices. Obstet Gynecol Surv. 1996;51(12 Suppl):S42-51.
15. Gemzell-Danielsson K, Marions L. Mechanisms of action of mifepristone and levonorgestrel when used for emergency contraception. Hum Reprod Update. 2004;10(4):341-8.

16. Wanggren K, Stavreus-Evers A, Olsson C, Andersson E, Gemzell-Danielsson K. Regulation of muscular contractions in the human Fallopian tube through prostaglandins and progestagens. Hum Reprod. 2008;23(10):2359-68.

17. Cleland K, Raymond E, Trussell J, Cheng L, Zhu H. Ectopic pregnancy and emergency contraceptive pills: a systematic review. Obstet Gynecol. 2010;115(6):1263-6.

18. Ortiz ME, Croxatto HB. Copper-T intrauterine device and levonorgestrel intrauterine system: biological bases of their mechanism of action. Contraception. 2007;75(6 Suppl):S16-30.

19. Center for Disease Control and Prevention. US medical eligibility criteria for contraceptive use. MMWR. 2010;59(No.RR-4):1-85. 